\title{
Analysis of Sexual Behavior of Junior High School Students X in Indramayu and the Idea of Learning
}

\author{
Eka Agni Anggini ${ }^{1}$, Yusuf Hilmi Adisendjaja ${ }^{1}$ and Didik Priyandoko ${ }^{1}$ \\ ${ }^{1}$ Program Studi Pendidikan Biologi, Sekolah Pascasarjana Universitas Pendidikan Indonesia, \\ Jl. Dr. Setiabudi No. 229, Bandung 40154, Indonesia
}

\begin{abstract}
Adolescence is a period of vulnerability to risky sexual behavior. Reproductive learning in biology subjects has an important role in providing information about reproduction and its relation to sexual behavior. So, students are not involved in sexual behavior that violates norms and religions. This study aims to analyze the sexual behavior of students of Junior High School X in Indramayu. The sample used in this research is 32 students with rondom sampling technique. The instrument used in this research is questionnaire, sexual behavior questionnaire using Likert scale.Technique analysis that are used in this research are student questionnaire analysis and analysis of interview result. The results show that the sexual behavior of junior high school students is on the autoerotic aspect consisting of 39\% fantasy sub-aspect, and $82 \%$ masturbation aspect, then on the sociosexual aspect on touching sub-aspect 40\%, necking 41\%, kissing $41 \%$, petting $27 \%$ and intercourse $22 \%$. The high level of premarital sexual behavior of teenagers is influenced by several factors such as spiritual education and supervision from parents, association, technology and reproductive health education at school. Learning ideas that can be applied in schools include integrating biology learning with sex education, linking with issues of reproductive health and through learning media such as posters, short films and others.
\end{abstract}

Keywords: adolescence, sexual behavior, autoerotic aspect, sociosexual aspect, junior high school.

\section{Introduction}

Adolescence is characterized by the onset of puberty. Puberty (puberty) is a period of rapid physical maturation, hormonal changes and body changes that take place during early adolescence. Adolescence is a period transition from childhood to adulthood. During this period of physical and psychological changes happen [2]. The four determinants of puberty include [1]:

\subsection{Genes}

Puberty has been programmed within the genes of every human being. Nevertheless, environmental factors also affect the appearance of puberty and the length of puberty, one of the environmental factors that nutrition intake plays an important role in adolescent development.

\subsection{Hormones}

Events of hair growing in the face such as the appearance of the first mustache, the enlargement of the voice in men and the enlargement of breasts in women, due to hormones. Hormones are chemicals created by the endocrine glands and circulated throughout the body through the blood.Testosterone is an androgen that plays an important role in the development of puberty in men. Testosterone plays a role in the development of secondary male sex features such as the growth of facial hair (mustache, beard), enlarged sound.Estradiol is an estrogen that plays an important role in the development of female puberty. Estrogen plays a role in the development of the reproductive system and secondary sex traits of women such as pelvic enlargement and breasts. 


\subsection{Endocrine Systems}

The endocrine system plays a role by involving the interactions of the hypothalamus, pituitary gland, and gonads (the sex glands) in puberty.

\subsection{Body Weight}

Body weight, taller and heavier bodies have strong links with menarche. girls who mature early tend to have higher body characteristics, more fat bodies [7].

Current problems relate to teenage sexuality such as teenage pregnancy and sexually transmitted diseases. Nowadays puberty takes place early which may lead to earlier sex and courtship activities, in contrast to previous generations. In view of storms and stress by G. Stanley Hall, which states that adolescence is a time of turmoil that is filled with conflicts and changes in hearts. Therefore, many teenagers are experimenting with risky sexual activity. From these statements it can be taken a synthesis that adolescence is a period of vulnerability to conflicts due to various changes both psychically and physically which are characteristic of the transition of childhood into adulthood.

Characteristics of puberty in boys and girls, the pubic characteristic of boys is enlargement and lengthening of the penis size, enlargement of the testes, the growth of pubic hair, the growth of hair in the armpit, the growth of facial hair (mustache, beard), the body increases, the enlarged voice, the first ejaculation (spermarche). The three most prominent sexual characteristic sexual characteristics in adolescent boys are enlarging and lengthening the size of the penis, enlarging the testicles, and the growth of facial hair (mustache, beard).

While the characteristics of puberty in girls of breast enlargement, the growth of pubic hair, the growth of hair in the armpit, height increased body, hips widened, at the end of the puberty cycle occurs first menstruation (menarche). Two of the most prominent characteristics in female adolescents are growing pubic hair and breast enlargement. Every individual has a tempo and the speed of puberty is different. In men, ages 10 to 13.5 years begin puberty, whereas in women, puberty begins at ages of 9 to 15 years [1].

Sexual desire arises with the maturation of sexual functions in adolescents. Physical and psychological changes that occur bring anxiety and confusion in adolescents. Some adolescents are able to cope, but the others experience stress and conduct behaviors that pose a risk to their health and welfare such as risky experiments and sexual explorations [3].Adolescents are vulnerable to risky sexual behavior and adolescents have little knowledge about contraception, resulting in an increase in the number of unwanted pregnancies in adolescents and most of them are at risk of unsafe abortion, HIV (Human Immunodeficiency Virus/Acquired Immunodeficiency Syndrome) and sexually transmitted diseases contagious. Abortion done illegally (either done alone or with others) can cause death.

Adolescence is a very vulnerable period with various reproductive health problems. Two most common problems of teen sexual behavior are unwanted pregnancies and sexually transmitted diseases [4]. It is in line with BKKBN which states that adolescents (aged 10-24 years) are vulnerable to reproductive health problems such as premarital sexual behavior, drugs, and HIV/AIDS [5]. Case data from January to October 2014 on teenage sexuality from Indramayu's Office District of Health Youth Reproductive Health Sector (KRR) include 589 premarital sexual behaviors, 34 deliveries, 66 abortions, 73 unwanted pregnancies, 235 sexually transmitted infections, 19 HIV / AIDS [6].

Adolescence is divided into two periods. Early adolescence takes place (around the age of 13 to 16 years) from early high school to last high school, and in this period of the largest biological and psychological changes, the late adolescence occurrs around the age of 18 years [7].

Badan Kependudukan dan Keluarga Berencana Nasional (BKKBN) states that every year in Indonesia there are about 2,000,000 cases of abortion. In West Java, approximately 400 thousand cases of abortion occur each year, almost partially done by adolescents [5]. Young people aged 15-25 account for 19\% of illegal abortions in a country [8]. Cumulative AIDS patients in West Java from 2004 to 2012 are as many as 4865 cases. The average every year in West Java finds AIDS cases as many as 540 cases [9]. These statistics show the 
vulnerability of adolescence especially with reproduction health problems, so that adolescents need serious attention from various circles such as family, environment, school, and others. Parents in the family have a major role in educating and supervising their children. In addition to family, the environment has an important influence because the environment is where teenagers interact with their friends and the community, then the school which is a place to learn to change behavior better.

The current curriculum of education in Indonesia is the 2013 curriculum whose objectives include four competencies: spiritual attitude competence, social attitude competence, knowledge competence, and skill competence. The formulation of spiritual attitudes is to appreciate and appreciate the religious teachings, it means that after students learn about the chapter of the human reproductive system in junior high school, students are expected to grow their consciousness, mirrored through students' attitudes in accordance with what he ordered (one such as: reproductive health) and stay away from HIS prohibitions (one of which is not having premarital sexual intercourse or risky sexual behavior).

The formulation of social attitude is showing honesty, discipline, responsibility, careing, courtesy, confidence in interacting effectively with social and natural environment within the reach of social and its existence. It means that after students learn about the reproduction system, students who already have awareness has a sense of responsibility, care for himself and his environment so that when positive values are embedded within each individual it will create an environment with a healthy society both psychically and physically.

Knowledge competence in the chapter of the reproduction system is more specific to the basic competence of 3.1 that is connecting the human reproduction system and disturbance to the reproduction system with the application of lifestyle that supports reproductive health. Skill competence is poured to the basic competence 4.1 presenting the results of information search from various sources related to health and efforts to prevent interference in the reproductive organs. The findings in the field, biology learning in junior high schools on reproduction system materials still use lecture methods and do not associate with the application of lifestyle that supports reproductive health, reproductive health problems (such as reproductive health myths, sexual behavior) shows that the implementation of the curriculum 2013 in the field has not gone well.

In field findings, biology learning in junior high schools on reproductive system materials still uses lecture methods and does not relate to reproductive health problems (such as : reproductive health myths, sexual behavior). This shows that the implementation of the 2013 curriculum in the field has not gone well. The current biology learning process in school, the learning model that is still frequently used, is lecture and monoton [10]. Sex education is an integral part of biological education in junior and senior high schools [11]. One of the factors that influence the high risk sexual behavior is the lack of sexual education in schools [12].

\section{Method}

This study aims to obtain information about the sexual behavior of junior high school students in Indramayu as well as the idea of learning. Subjects in this study are students of Junior High School X, XI grades in Indramayu. The sample used in this research is 32 students with rondom sampling technique. Sexual behavior that becomes the focus in this study refers to Katchandaurian (1980) which consists of aspects of autoerotism and sociosexual. The instrument used to collect data on sexual behavior is by questionnaires and interviews. Sexual behavior questionnaire use Likert scale. The data obtained are analyzed descriptive.

\section{Results and Discussion}

The results obtained from data collection by using a new instrument of questionnaires about sexual behavior consisting of several aspects, namely autoerotism and sociosexual, are listed in Table 1.1. In addition the questionnaire data collection is also done by interviewing teachers, parents, and students.

Table 1.1 describes the students of junior high school class IX aged around 14-15 years from the table can rank the percentage of sexual behavior from the highest to the lowest $82 \%$ masturbation, $41 \%$ kissing, $41 \%$ necking, 40\% touching, 39\% fantasy , 27\% petting, and 22\% intercourse. Grafik 1 describes 30 students 
consisting of 16 male students and 16 female students who performed free sex as a whole were the highest percentage of male students is $19 \%$, while female students were $3 \%$.

Free sex is a behavior that violates religious norms. Risky sexual behaviors are defined as individual behaviors that increase the vulnerability of sexually transmitted infections (STIs) and HIV, and unwanted pregnancies [13].

Having premarital sex in adolescents is at risk for unwanted pregnancy, abortion, and sexually transmitted diseases [14]. Based on interviews with teachers, students and parents, there are several factors that influence adolescents to engage in risky sexual behavior such as:

\subsection{Spiritual Education and Supervision of Parents}

Spiritual education is the main thing that should be instilled in children, because the spiritual education is the main foundation to avoid risky sexual behavior. There are three aspects of the role of parents that influence adolescents to engage or not engage in free sex: parent-child relationships, family conflicts level, and parental monitoring [14]. The findings in the field reveal that most parents are still taboo discuss about reproductive health and sexuality with their children, talking about things about reproduction and sexuality with their children is considered as forbidden. Thus, many teenagers are searching for information from false and uneducated sources. Parents are important factor that affects teenagers having free sex.

\subsection{Association}

Adolescents are people who have a high curiosity, when adolescents get little supervision and spiritual education of their parents then the teenager will do the exploration to meet his curiosity without any restrictions on norms and religions and can be brought bad association and the risk of free sex. Factors related to sexual risk taking include: socio-economic status and family / care, self-regulation (the ability to regulate one's emotions and behaviors) [1].

\subsection{Technology}

The rapid technological advancement and rapid development of information is now one of the factors that influence adolescents to engage in risky sexual behavior. Using unattended internet will allow teenagers to access information indefinitely to satisfy all their curiosity and passion, especially any information about sex.

\subsection{Education at School}

Students spend much of their time not only at home but also at school. Therefore schools have an important role in providing information about sexual behavior, especially biology subjects. Behavioristic theory states that learning is a behavioral change (behavior) resulting from experience gained. Biology education plays an important role in assessing reproductive health and providing information to students to be more concerned with their reproductive health.

Based on the results of interviews, the biology subjects in the reproductive chapter are mostly presented with lecture methods and some teachers do not relate to sexual behavior issues and some teachers are still confused by the method of applying to convey to junior high school students about sexual behavior.

Currently, teenagers are not ashamed to show off in public such as holding hands, hugging, kissing,

other affectionate behavior even upload it on his social media.The findings in the field, most of them are familiar with alcohol, and some others are already taking drugs.Education within the family, the environment as well as in schools has an important role in providing more positive changes in adolescent reproductive health issues that occur today, so that adolescents can prevent themselves from doing behaviors that are at risk for reproductive health.

Learning ideas that can be applied in biology learning activities include integrating sexual education in biology subjects [11], linked to reproductive health issues and sexual behavior that exist in society [15], using learning media such as posters, short films [16]. 
TABLE I: Sexual Behavior of Junior High School X's Student

\begin{tabular}{|l|l|l|l|}
\hline \multirow{4}{*}{ Sexual Behavior } & Aspect & Sub-aspect & Student \\
\cline { 2 - 4 } & \multirow{3}{*}{ Autoerotism } & Fantasy & $39 \%$ \\
\cline { 3 - 4 } & & Masturbation & $82 \%$ \\
\cline { 2 - 4 } & \multirow{4}{*}{ Sociosexual } & Touching & $40 \%$ \\
\cline { 3 - 4 } & Kissing & $41 \%$ \\
\cline { 3 - 4 } & Necking & $41 \%$ \\
\cline { 3 - 4 } & & Petting & $27 \%$ \\
\cline { 3 - 4 } & & Intercourse & $22 \%$ \\
\hline \multirow{4}{*}{} & &
\end{tabular}

Chart 1: Adolescents who have intercourse and Adolesecent who don't have intercourse

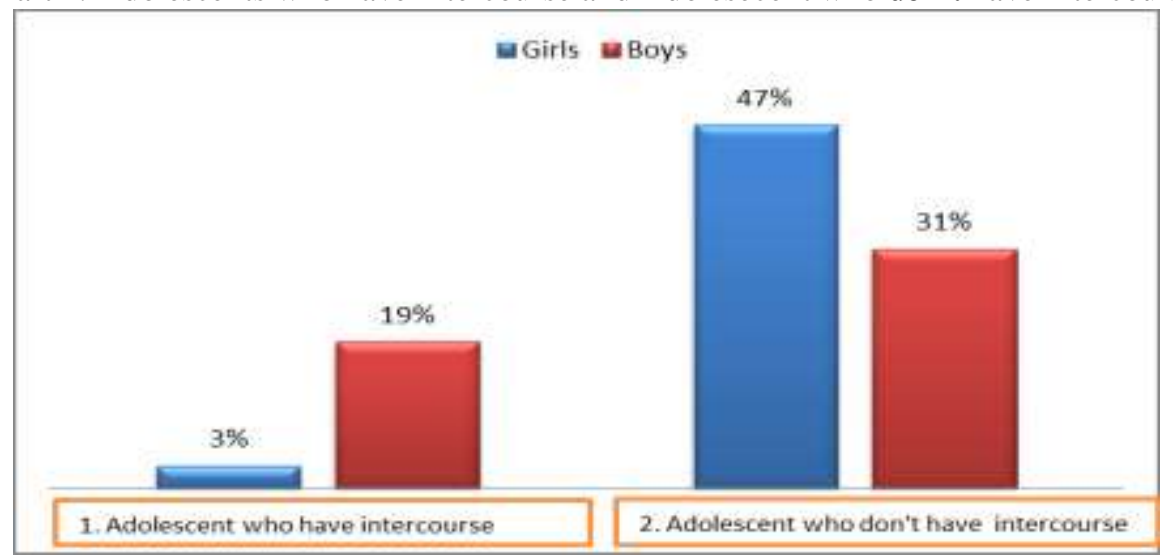

\section{Conclusions}

Class IX students aged around 14-15 years can rank the percentage of sexual behavior from the highest to the lowest of $82 \%$ masturbation, $41 \%$ kissing, $41 \%$ necking, $40 \%$ touching, $39 \%$ fantasy, $27 \%$ petting, and intercourse $22 \%$. some of the factors that influence adolescents to engage in risky sexual behavior are spiritual education and parental supervision, association, technology advances (handphone, laptop, internet, social media), and schooling.

\section{Acknowledgments}

The authors wish to thank Dr. Yusuf Hilmi Adisendjaja, M.Sc and Dr. Didik Priyandoko, M. Si who has guided in researching and writing this article. the authors also say thank you to the junior high school $\mathrm{X}$ that has helped the authors in the research.

\section{References}

[1] Santrock, J.W (2007). Adolescence. (5th Edition). New York: McGraw-Hill Company Inc.

[2] Steinberg. 1993. Adolescence. Third Edition. Newyork: McGraw-Hill.

[3] Esere, M. O. 2008. Effect of sex education programme on at-risk sexual behaviour of school-going adolescents in Ilorin Nigeria. African Health Science. 8(2). pp. 120-125.

[4] Katchadourian, H. 1980. Adolescent sexuality. Pediatric Clinics of North America. [Online] 27(1). pp. 17-88. https://www.ncbi.nlm.nih.gov/pubmed/6892846

[5] BKKBN. 2011. Kajian Profil Penduduk Remaja (10-24 THN). [Online]. https://www.scribd.com/document/174140091/Kajian-Profil-Penduduk-Remaja-10-24-Tahun\# (22 Mei 2017)

[6] Marlia, T. 2015. Determinan Praktik Seksual Pranikah pada Remaja di Indramayu. Jurnal Kesehatan Masyarakat. 1(3). pp. 6-13. 
[7] Hurlock, E. B. (1980). Psikologi Perkembangan Suatu Pendekatan Sepanjang Rentang Kehidupan, Edisi 5. Jakarta: Erlangga.

[8] Silva, I., Rankapuge, L., \& Perera, R. 2000. Induced Abortion in Sri Lanka: Who Goes to Providers for Pregnancy Termination. Department of Demography, University of Colombo.

[9] Depkes. 2012. Profil Kesehatan Provinsi Jawa Barat Tahun 2012. [Online]. Diakses dari www.depkes.go.id (25 April 2017)

[10] Muldayanti, N. D. 2013. Pembelajaran Biologi Model STAD dan TGT Ditinjau dari keingintahuan dan minat belajar siswa. Jurnal Pendidikan IPA Indonesia, 2(1). pp. 12-17.

[11] Iwu, R. U., Onoja, A. I., Ijioma, B. C., Ngumah, M. O. And Egeruoh, A. S. 2011. International Journal of Science and Technology Education Research, 2(4). pp. 62-66.

[12] Ekstrand, M., Larsson, M., Essen, L., \& Tyde'n, T. 2005. Acta Obstet Gynecol Scand, 84(1). pp. 980-986.

[13] Luster, T. \& Small, S. A. 1996. Factors Associated with Sexual Risk-Taking Behaviors among Adolescents. Journal of Marriage and Family. 56(3). pp. 622-632.

[14] Dilorio, C., Dudley, W. N., Soet, J. E., \& McCarty, F. 2004. Sexual possibility situations and sexual behaviors among young adolescents: The moderating role of protective factors. Journal of Adolescent Health. 35 (1). pp. 528.e11528.e20.

[15] Nyika, L., Manguvo, A. and Zinyanduko, F. 2016. Reflexivity in Sexual Health Pedagogy. Pedagogy in Health Promotion. 1(3). pp. 239-243.

[16] Cardoza, V.J., Docum, P.I., Fryer S.G., Gold, M.A., \& Butler, J. 2011. Sexual Health Behavior Interventions for U.S. Latino Adolescents: A Systematic review of the literature. Journal of Pediatric and Adolescent Gynecology. 